\title{
Modification of the Penn State Forage and Total Mixed Ration Particle Separator and the Effects of Moisture Content on its Measurements
}

\author{
P. J. Kononoff, ${ }^{\star}$ A. J. Heinrichs, ${ }^{\star}$ and D. R. Buckmaster† \\ *Department of Dairy and Animal Science \\ †Department of Agricultural and Biological Engineering \\ The Pennsylvania State University \\ University Park, PA 16802
}

\begin{abstract}
The Penn State Particle Separator has led to widespread measurement of forage and total mixed ration (TMR) particle size. However, a large proportion of small particles may pass through both sieves when a TMR is analyzed, and field research has suggested that both shaking frequency and sample dry matter may affect the results. The objectives of this project were to test the effects of an additional sieve with a smaller aperture size, shaking frequency, and sample moisture content on results obtained. A sieve was constructed out of wire with a nominal size aperture of $1.18 \mathrm{~mm}$. Samples of alfalfa haylage, corn silage, and a TMR were shaken at frequencies of $0.9,1.1$, and $1.6 \mathrm{~Hz}$ with a 17 $\mathrm{cm}$ stroke length. Reducing shaking frequency to 0.9 $\mathrm{Hz}$ resulted in more material being retained on the 19.0$\mathrm{mm}$ sieve for all sample types, increasing the geometric mean. Increasing frequency to $1.6 \mathrm{~Hz}$ did not affect the geometric mean, but did result in a greater amount of corn silage falling through the 1.18-mm sieve. For alfalfa haylage, moisture content between 57.4 and $35.6 \%$ did not affect results; however, for corn silage, less moisture increased the percentage of particles less than 1.18 $\mathrm{mm}$ and decreased the geometric mean. For both sample types, further drying caused a greater proportion of small particles and a smaller geometric mean. We suggest using a third sieve and shaking at $1.1 \mathrm{~Hz}$ or greater with a stroke length of $17 \mathrm{~cm}$ when using the Penn State Particle Separator to analyze forage particle size.
\end{abstract}

(Key words: moisture, particle size, sieve)

Abbreviation key: $\mathbf{S}_{\mathbf{g m}}=$ geometric standard deviation, PSPS = Penn State Particle Separator, $\mathbf{X}_{\mathbf{g m}}=$ geometric mean.

Received January 16, 2002.

Accepted July 18, 2002.

Corresponding author: A. J. Heinrichs; e-mail: ajh@psu.edu.

\section{INTRODUCTION}

The ability of a ration to meet the nutritional needs of a high yielding dairy cow requires understanding of both the chemical and physical characteristics of the ration. Increasing fiber level and forage particle size has been shown to effectively increase chewing activity and is believed to increase saliva flow, rumen $\mathrm{pH}$, acetate-to-propionate ratio and milk fat levels (Beauchemin et al., 1997). Although impaired rumen fermentation and function can result from rations lacking in physical structure, excessive amounts of long, coarse forage may also limit intake and digestibility, ultimately affecting the energy balance of the animal (Allen, 1997). As the particle size of grain particles decreased, the area available for microbial attack increased, resulting in a greater extent of rumen fermentation (San Emeterio et al., 2000). Although the effects of particle size on rumen function and fermentation have been well-documented (Grant et al., 1990a, 1990b; Fischer et al., 1994), routine on-farm analysis of this ration characteristic has only recently gained attention.

Based on properties of the standard S424 of the American Society of Agricultural Engineers (2001) for forage particle size determination, the Penn State Particle Separator (PSPS) is a quick and cost-effective method of analysis. The manually operated PSPS is constructed out of two sieves and a bottom pan. Apertures of the two sieves measure 19.0- and 8.0-mm with a thickness of 12.2 and $6.4 \mathrm{~mm}$. With its simple construction and size, the PSPS sieving method may be implemented on farm and used at the time of harvest or feeding to determine particle size of forages or TMR (Lammers et al., 1996). Even though the apparatus has been widely accepted and particle size measurements using the PSPS are now commonly reported in the literature, TMR typically contain 40 to $60 \%$ concentrate, most of which passes through the $8.0-\mathrm{mm}$ sieve. Measurement of smaller particles may be useful in understanding the effects of ration particle size on rumen function and fermentation, as it has been suggested that $1.18 \mathrm{~mm}$ 
is the critical length governing retention in the reticulorumen (Poppi and Norton, 1980).

Although the rationale behind all published sieving methods is similar, the equipment, method, or physical form of the sample may vary and affect particle size measurement (Murphy and Zhu, 1997). Operation of the PSPS has been previously described (Lammers et al., 1996); however, during our field experience we have observed that the rate of shaking, and, as a result, the effectiveness of separation often differs between users. This observation suggests that directions for use of the PSPS may require further refinement. Furthermore, because the PSPS has been adopted as an analytical technique by some feed testing laboratories, the procedure must be clearly defined so that calibration is possible. Few studies have evaluated the effect of sample moisture content on particle size measurements. Because moisture content often differs depending on harvest time, weather and other factors, the effect of moisture content on particle size measurements should be further investigated.

The objectives of this project were as follows: 1) to modify the PSPS so that smaller particles can be further partitioned during measurement, 2) to define optimal sieving motion for the PSPS, and 3) to determine the effect of sample moisture on sieving results.

\section{MATERIALS AND METHODS}

\section{Modifications of the Penn State Forage and TMR Particle Separator}

An addition to the PSPS was developed. The third sieve was inserted in the identical casing of the original sieves but contained stainless steel wire cloth, consisting of nominal size apertures of $1.8 \mathrm{~mm}$ and diagonal apertures of $1.67 \mathrm{~mm}$ (Gilson Company, Lewis Center, $\mathrm{OH})$.

\section{Method of Separation}

In testing the effects of shaking frequency and sample moisture on measurements taken by the PSPS, operation of the device was similar to that described by Lammers et al. (1996). The sieves were stacked in the following order: $19.0-\mathrm{mm}$ plastic sieve on top, $8.0-\mathrm{mm}$ plastic sieve second, followed by $1.18-\mathrm{mm}$ metal sieve, and the plastic pan fitted to the bottom of the last sieve. Approximately $1.4 \pm 0.5 \mathrm{~L}$ of sample was spread out on the top $19.0-\mathrm{mm}$ sieve. The sieve set was shaken horizontally five times in one direction, then rotated one fourth turn, and again shaken five times. The procedure was repeated for eight sets of five replications for a total of 40 shakes. Rotation of the separator ensured that the sample was thoroughly shaken and that particles were not stacked upon each other. One shake was considered as a forward and backward motion over a distance of $17 \mathrm{~cm}$. Particles were assumed to be logarithmically normally distributed and geometric mean $\left(\mathbf{X}_{\mathbf{g m}}\right)$ and standard deviation $\left(\mathbf{S}_{\mathbf{g m}}\right)$ were calculated as outlined by the ASAE Standard (2001).

\section{Testing Effect of Sieving Frequency on Particle Size Measurement}

To test the effect of shaking frequency on particle size measurement, samples of alfalfa haylage, corn, silage and a TMR were collected and analyzed in duplicate for particle size using three different frequencies. The three frequencies used in the experiment were 0.9 (slow), 1.1 (medium), and $1.6 \mathrm{~Hz}$ (fast). All replications were timed so that sieving frequencies were consistent between duplications. Sample moisture contents of alfalfa haylage, corn silage, and a TMR were 64.6, 67.4, and $46.0 \%$, respectively.

\section{Testing Effect of Sample Moisture in Particle Size Measurement}

Approximately $1.4 \mathrm{~L}$ subsamples of alfalfa haylage and corn silage were evenly spread out on individual aluminum pans and placed in a large forced air oven set at $55^{\circ} \mathrm{C}$. Five times over a 48 -h period approximately three subsamples, each contained in individual pans, were removed from the oven and analyzed for particle size. Alfalfa haylage samples were removed from the oven and analyzed for particle size after drying $0,2,6$, 12 , and $48 \mathrm{~h}$, while corn silage samples were dried for $0,3,6,18$, and $48 \mathrm{~h}$.

\section{Statistical Analysis}

All data were analyzed as a completely randomized design using the REML variance component and MIXED procedure of SAS Version 8.1 (2001). Mean separation was determined using the PDIFF procedure and significance was declared at $P<0.05$. The model used to evaluate effect of sieving frequency and sample moisture content on particle size measurements was:

$$
\mathrm{y}_{\mathrm{ij}}=\mu+\delta_{\mathrm{i}}+\varepsilon_{\mathrm{ij}}
$$

where:

$$
\begin{aligned}
\mathrm{y}_{\mathrm{ij}}= & \text { percent of sample retained on each sieve, } \\
& \text { geometric mean or standard deviation, } \\
\mu= & \text { overall mean, } \\
\delta_{\mathrm{i}}= & \text { fixed effect of treatment (sieving fre- } \\
& \text { quency or percent moisture) }
\end{aligned}
$$


$\varepsilon_{\mathrm{ij}}=$ residual error, assumed to be normally distributed.

\section{RESULTS AND DISCUSSION}

\section{Modification of the Penn State Forage and TMR Particle Separator}

The original PSPS has proven valuable in measuring feed particle size, but in a survey of 831 TMR samples, Heinrichs et al. (1999) reported an average of $57.7 \%$ of the material passes through both sieves. Better characterization of these smaller feed particles requires a sieve designed to further partition particles $<8.0 \mathrm{~mm}$. Additionally, it has been suggested that $1.18-\mathrm{mm}$ is the critical length governing retention in the reticulorumen. Thus, measurement of particle mass $<1.18 \mathrm{~mm}$ may be useful in interpreting results of experiments evaluating the effects of feeding diets of varying physical form (Poppi and Norton, 1980; Mertens, 1997). An additional sieve containing a nominal aperture measuring $1.18 \mathrm{~mm}$ and diagonal aperture of $1.67 \mathrm{~mm}$ was added to the sieving device.

\section{Presentation of Sieving Results and Particle Size Measurements}

Particle size analysis attempts to determine the actual frequency distribution of particles according to size (Irani and Callis, 1964). Material retained on each sieve is expressed in tabular form as seen in Tables 1, 2, and 3 . Because of the wide variety of feeds analyzed and the various types of sieving techniques employed, a variety of mathematical forms of particle size distribution have been investigated. Finner et al. (1978) described a method of sieving based on a lognormal distribution, which was subsequently adopted by the American Society of Engineers for describing forage particle size (ASAE, 2001). Smith et al. (1984) determined that an exponential distribution might fit data for alfalfa, grass and corn silages. Fisher et al. (1987) found an exponential distribution fit particle size data of digesta of cattle grazing bermudagrass and Allen et al. (1984) reported a gamma fit distribution was more accurate than lognormal distributions in describing ground hay. Lastly, the original description of the PSPS recommended a Weibull distribution rather than lognormal because plots were more linear and did not require transformation, thereby simplifying plotting and interpretation (Lammers et al., 1996). The use of a Weibull distribution was in agreement with the analysis of Pitt (1987).

Although the best fit of a specific mathematical distribution may depend on the method of sieving, sample type, and nature of processing, the lognormal approach may be more convenient because other distributions are more mathematically complex and estimation of their parameters is more difficult. Kolmogoroff (1941) was the first to describe a lognormal distribution with respect to ground particles. This approach is simple and results in derivation of two useful parameters, the $\log$ mean $(\log \mu)$ and $\log$ standard deviation $(\log \sigma)$ resulting in estimates of the sample geometric mean $\left(\mathrm{X}_{\mathrm{gm}}\right)$ and standard deviation $\left(\mathrm{S}_{\mathrm{gm}}\right)$ (O'Dogherty, 1984). Consequently, if the lognormal fits the actual distribution closely, information to describe the distribution can be calculated, interpreted and reported easily. Data presention in this study includes both geometric mean and standard deviation with data assumed to be logarithmically normally distributed, an idea concurrent to the ASAE standard (ASAE, 2001).

\section{Sieving Frequency and Particle Size Measurement}

The force and frequency of shaking motion must be sufficient so that the particles slide over the sieve surface allowing those smaller than the aperture to fall through. According to the ASAE standard (S424) the sieve stack should be driven with a frequency of $2.4 \pm$ $0.08 \mathrm{~Hz}$ (144 \pm 5 cycles/min); however, the PSPS is manually operated, and this specification is not practically possible and may explain occasional differences between the devices (Lammers et al., 1996). Because sieving frequency of the PSPS has never been specified, we evaluated the effect of frequency on particle size measurements so that recommendations could be formulated. Sieving alfalfa haylage, corn silage and TMR at different frequencies results in significant $(P<0.05)$ differences in particle size measurements (Table 1). Reducing sieving frequency below $1.1 \mathrm{~Hz}$ to $0.9 \mathrm{~Hz}$ resulted in significantly $(P<0.05)$ more material being retained on the $19.0-\mathrm{mm}$ sieve and less on the $8.0-$ and $1.18-\mathrm{mm}$ sieves for all sample types. As a consequence of these results, $\mathrm{X}_{\mathrm{gm}}$ was significantly $(P<0.05)$ greater when material was sieved at $0.9 \mathrm{~Hz}$ compared to $1.1 \mathrm{~Hz}$. In contrast, increasing sieving frequency from 1.1 to 1.6 $\mathrm{Hz}$ did not result in significant differences $(P>0.05)$ in particle size measurements of $\mathrm{X}_{\mathrm{gm}}$ calculations for either alfalfa haylage or TMR samples. Although increasing sieving frequency from 1.1 to $1.6 \mathrm{~Hz}$ for corn silage significantly increased the amount of material falling through the $1.18 \mathrm{~mm}$ sieve, these differences were not reflected in $\mathrm{X}_{\mathrm{sm}}$ which were not significantly $(P>0.05)$ different (11.2 and $11.6 \mathrm{~mm})$.

As a result of this study, we recommend the PSPS to be shaken at $1.1 \mathrm{~Hz}$ (66 cycles/min) or greater with a stroke length of $17 \mathrm{~cm}$. It is recommended that operators of the device calibrate the frequency of movement over a distance of $17 \mathrm{~cm}$ for a specified number of times. 
Table 1. Effects of sieving frequency on particle size measurements of alfalfa haylage,${ }^{1}$ corn silage,${ }^{2}$ and $\mathrm{TMR}^{3}$ samples as measured by the modified Penn State Particle Separator using a 17-cm stroke.

\begin{tabular}{|c|c|c|c|c|c|}
\hline \multirow[b]{2}{*}{ Particle size $(\mathrm{mm})$} & \multicolumn{3}{|c|}{ Frequency $(\mathrm{Hz})$} & \multirow[b]{2}{*}{ SEM } & \multirow[b]{2}{*}{$P$-value } \\
\hline & 0.9 & 1.1 & 1.6 & & \\
\hline \multicolumn{6}{|l|}{ Alfalfa haylage } \\
\hline$>19.0$ & $85.3^{\mathrm{a}}$ & $20.6^{\mathrm{b}}$ & $16.5^{\mathrm{b}}$ & 3.78 & $<0.01$ \\
\hline $19.0-8.0$ & $6.8^{\mathrm{b}}$ & $50.1^{\mathrm{a}}$ & $56.5^{\mathrm{a}}$ & 3.14 & $<0.01$ \\
\hline $8.0-1.18$ & $7.5^{\mathrm{b}}$ & $27.3^{\mathrm{a}}$ & $24.6^{\mathrm{a}}$ & 0.64 & $<0.001$ \\
\hline$<1.18$ & $0.40^{\mathrm{b}}$ & $2.0^{\mathrm{a}}$ & $2.4^{\mathrm{a}}$ & 0.27 & 0.03 \\
\hline $\mathrm{X}_{\mathrm{gm}}(\mathrm{mm})^{5}$ & $23.8^{\mathrm{a}}$ & $10.1^{b}$ & $10.4^{b}$ & 0.66 & 0.001 \\
\hline $\mathrm{S}_{\mathrm{gm}}(\mathrm{mm})^{6}$ & $1.85^{\mathrm{b}}$ & $2.3^{\mathrm{a}}$ & $2.2^{\mathrm{a}}$ & 0.05 & 0.02 \\
\hline \multicolumn{6}{|l|}{ Corn silage ${ }^{2}$} \\
\hline$>19.0$ & $71.2^{\mathrm{a}}$ & $9.0^{\mathrm{b}}$ & $10.9^{\mathrm{b}}$ & 1.60 & $<0.001$ \\
\hline $19.0-8.0$ & $23.4^{\mathrm{b}}$ & $77.2^{\mathrm{a}}$ & $77.1^{\mathrm{a}}$ & 1.81 & $<0.001$ \\
\hline $8.0-1.18$ & $5.3^{\mathrm{c}}$ & $13.4^{\mathrm{a}}$ & $11.2^{\mathrm{b}}$ & 0.35 & $<0.01$ \\
\hline$<1.18$ & $0.10^{\mathrm{c}}$ & $0.40^{\mathrm{b}}$ & $0.80^{\mathrm{a}}$ & 0.03 & 0.03 \\
\hline $\mathrm{X}_{\mathrm{gm}}(\mathrm{mm})^{5}$ & $21.8^{\mathrm{a}}$ & $11.2^{\mathrm{b}}$ & $11.6^{\mathrm{b}}$ & 0.15 & $<0.0001$ \\
\hline $\mathrm{S}_{\mathrm{gm}}(\mathrm{mm})^{6}$ & 1.77 & 1.71 & 1.74 & 0.03 & 0.49 \\
\hline \multicolumn{6}{|l|}{$\mathrm{TMR}^{3,4}$} \\
\hline$>19.0$ & $40.9^{\mathrm{a}}$ & $6.4^{\mathrm{b}}$ & $6.9^{\mathrm{b}}$ & 4.87 & 0.02 \\
\hline $19.0-8.0$ & $24.6^{\mathrm{b}}$ & $42.9^{\mathrm{a}}$ & $43.8^{\mathrm{a}}$ & 3.50 & 0.05 \\
\hline $8.0-1.18$ & 31.5 & 36.7 & 35.3 & 2.00 & 0.31 \\
\hline$<1.18$ & $3.0^{\mathrm{b}}$ & $14.0^{\mathrm{a}}$ & $14.0^{\mathrm{a}}$ & 0.56 & 0.001 \\
\hline $\mathrm{X}_{\mathrm{gm}}(\mathrm{mm})^{5}$ & $11.2^{\mathrm{a}}$ & $5.8^{\mathrm{b}}$ & $5.7^{\mathrm{b}}$ & 0.63 & 0.01 \\
\hline $\mathrm{S}_{\mathrm{gm}}(\mathrm{mm})^{6}$ & 2.70 & 2.76 & 2.78 & 0.07 & 0.74 \\
\hline \multicolumn{6}{|c|}{ a,b,c Means in the same row with different superscripts differ $(P<0.05)$. } \\
\hline \multicolumn{6}{|c|}{${ }^{1} 64.4 \pm 0.6 \%$ moisture. } \\
\hline \multicolumn{6}{|c|}{${ }^{2} 67.4 \pm 0.3 \%$ moisture. } \\
\hline \multicolumn{6}{|c|}{${ }^{3} 46.0 \pm 1.6 \%$ moisture. } \\
\hline \multirow{2}{*}{\multicolumn{6}{|c|}{$\begin{array}{l}{ }^{4} \mathrm{TMR} \text { containing } 50: 50 \text { forage to concentrate ratio and a } 9.5 \% \mathrm{DM} \text { grass hay, } 25.3 \% \mathrm{DM} \text { corn silage, and } \\
14.6 \% \mathrm{DM} \text { alfalfa haylage. }\end{array}$}} \\
\hline & & & & & \\
\hline \multicolumn{6}{|c|}{${ }^{5} \mathrm{X}_{\mathrm{gm}}=$ geometric mean len } \\
\hline
\end{tabular}

Number of full movements divided by time in seconds results in a frequency value that can be compared to this recommendation.

\section{Sample Moisture Content and Particle Size Measurement}

Although moisture content may affect sieving properties, it is not practical to recommend analysis at a standard moisture content during field measurements (Fin- ner et al., 1978). The PSPS is designed to describe particle size of the feed offered to the animal; thus it is recommended that samples should not be chemically or physically altered before sieving. Because sample moisture loss may occur during storage or transport, a study was carried out to determine the effects of forage moisture on particle size measurements made by the PSPS. Tables 2 and 3 outline the effect of forage moisture content on particle size measurement for both alfalfa haylage and corn silage. For alfalfa haylage oven

Table 2. Effects of alfalfa haylage moisture content on particle size measurements according to the Penn State Particle Separator shaken at $1.2 \mathrm{~Hz}$ with a stroke length of $17 \mathrm{~cm}$.

\begin{tabular}{|c|c|c|c|c|c|c|c|}
\hline \multirow[b]{2}{*}{ Particle size (mm) } & \multicolumn{5}{|c|}{ Percentage moisture } & \multirow[b]{2}{*}{ SEM } & \multirow[b]{2}{*}{$P$-value } \\
\hline & 57.4 & 35.6 & 10.4 & 2.5 & 0 & & \\
\hline$>19.0$ & $61.5^{\mathrm{a}}$ & $63.0^{\mathrm{a}}$ & $45.2^{\mathrm{b}}$ & $40.3^{\mathrm{b}}$ & $27.5^{\mathrm{b}}$ & 2.87 & $<0.001$ \\
\hline $19.0-8.0$ & $25.3^{\mathrm{c}}$ & $24.4^{\mathrm{c}}$ & $35.4^{\mathrm{b}}$ & $37.3^{\mathrm{a}, \mathrm{b}}$ & $44.5^{\mathrm{a}}$ & 2.25 & $<0.001$ \\
\hline $8.0-1.18$ & $11.3^{\mathrm{d}}$ & $10.6^{\mathrm{d}}$ & $15.1^{\mathrm{c}}$ & $18.0^{\mathrm{b}}$ & $22.6^{\mathrm{a}}$ & 0.69 & $<0.001$ \\
\hline$<1.18$ & $1.9^{\mathrm{c}}$ & $2.1^{\mathrm{c}}$ & $4.3^{\mathrm{b}}$ & $4.4^{\mathrm{b}}$ & $5.4^{\mathrm{a}}$ & 0.27 & $<0.001$ \\
\hline $\mathrm{X}_{\mathrm{gm}}(\mathrm{mm})^{1}$ & $17.7^{\mathrm{a}}$ & $17.9^{\mathrm{a}}$ & $13.7^{\mathrm{b}}$ & $12.6^{\mathrm{b}}$ & $10.3^{\mathrm{c}}$ & 0.54 & $<0.001$ \\
\hline $\mathrm{S}_{\mathrm{gm}}(\mathrm{mm})^{2}$ & $2.3^{\mathrm{b}}$ & $2.3^{\mathrm{b}}$ & $2.6^{\mathrm{a}}$ & $2.6^{\mathrm{a}}$ & $2.6^{\mathrm{a}}$ & 0.04 & $<0.001$ \\
\hline
\end{tabular}

a,b,c Means in the same row with different superscripts differ $(P<0.05)$.

${ }^{1} \mathrm{X}_{\mathrm{gm}}=$ geometric mean length as calculated by the ASAE (2001).

${ }^{2} \mathrm{~S}_{\mathrm{gm}}=$ standard deviation as calculated by ASAE (2001). 
Table 3. Effects of corn silage moisture content on particle size measurements according to the Penn State Particle Separator shaken at $1.2 \mathrm{~Hz}$ with a stroke length of $17 \mathrm{~cm}$.

\begin{tabular}{|c|c|c|c|c|c|c|c|}
\hline \multirow[b]{2}{*}{ Particle size (mm) } & \multicolumn{5}{|c|}{ Percent moisture } & \multirow[b]{2}{*}{ SEM } & \multirow[b]{2}{*}{$P$-value } \\
\hline & 58.0 & 34.4 & 14.6 & 3.47 & 0 & & \\
\hline$>19.0$ & 14.3 & 11.0 & 9.5 & 9.6 & 12.9 & 2.16 & 0.32 \\
\hline $19.0-8.0$ & $74.0^{\mathrm{a}}$ & $74.5^{\mathrm{a}}$ & $73.2^{\mathrm{a}}$ & $70.4^{\mathrm{a}}$ & $52.3^{\mathrm{b}}$ & 2.08 & $<0.001$ \\
\hline $8.0-1.18$ & $11.4^{\mathrm{d}}$ & $13.1^{\mathrm{c}, \mathrm{d}}$ & $15.4^{\mathrm{b}, \mathrm{c}}$ & $18.0^{\mathrm{b}}$ & $31.5^{\mathrm{a}}$ & 1.36 & $<0.001$ \\
\hline$<1.18$ & $0.23^{\mathrm{d}}$ & $1.36^{\mathrm{c}}$ & $2.0^{\mathrm{b}}$ & $2.0^{\mathrm{b}}$ & $3.4^{\mathrm{a}}$ & 0.16 & $<0.001$ \\
\hline $\mathrm{X}_{\mathrm{gm}}(\mathrm{mm})^{1}$ & $12.1^{\mathrm{a}}$ & $11.2^{\mathrm{b}}$ & $10.6^{\mathrm{b}, \mathrm{c}}$ & $10.2^{\mathrm{c}}$ & $8.62^{\mathrm{d}}$ & 0.33 & $<0.001$ \\
\hline $\mathrm{S}_{\mathrm{gm}}(\mathrm{mm})^{2}$ & $1.7^{\mathrm{d}}$ & $1.8^{\mathrm{c}}$ & $1.9^{\mathrm{b}, \mathrm{c}}$ & $2.0^{\mathrm{b}}$ & $2.3^{\mathrm{a}}$ & 0.03 & $<0.001$ \\
\hline
\end{tabular}

drying times of $0,2,6,12$, and $48 \mathrm{~h}$ resulted in moisture concentration $57.4,35.6,10.4,2.5$, and $0.0 \%$, respectively. Similarly, for corn silage oven drying times of 0 , $3,6,18$, and $48 \mathrm{~h}$ resulted in moisture concentrations of $58.0,34.4,14.6,3.5$, and $0.0 \%$, respectively. For alfalfa haylage samples, particle size measurements were not significantly different $(P>0.05)$ between 57.4 and $35.6 \%$ moisture indicating that moisture loss in samples within this range will not affect particle size measurements. Conversely, for corn silage the amount of particle mass $<1.18 \mathrm{~mm}$ was significantly different $(P<0.05)$ between 58.0 and $34.4 \%$ moisture and resulted in small but significant differences in $\mathrm{X}_{\mathrm{gm}}$. These results suggest that moisture loss from corn silage may affect particle size results; but these differences, when observed, are small. For alfalfa haylage, comparing to 57.4 and $35.6 \%$ moisture, the amount of material $>19.0 \mathrm{~mm}$ was significantly lower in samples containing $10.4,2.5$, and $0.0 \%$ but this difference was not observed for corn silage as most material $>19.0 \mathrm{~mm}$ contained cob particles for which size measurement appeared to be unaffected $(P$ $>0.05$ ) by moisture content. For both forages, amount of material $<1.18 \mathrm{~mm}$ was greatest at $0.0 \%$ moisture content while $\mathrm{X}_{\mathrm{gm}}$ decreased with decreasing moisture content. These results are similar to Finner et al. (1978) who suggested that completely drying a sample results in shattering of particles and further size reduction during the sieving process. Differences in sieving results associated with sample drying may have been due to brittle particles that shatter during shaking or to decreased adhesion of small particles to larger ones when materials are dry.

Because it would be impractical to recommend a constant sample moisture for measuring forage or TMR particle size during field measurement, it is advantageous to know that slight losses of moisture have only limited effects on measurements according to the moisture range of this study. Although it is recommended that samples be analyzed in the same physical form as that fed to the animal and moisture loss in the samples should be minimized, based on our results only small differences result when sample moisture loss is approximately $40 \%$ of the original sample.

\section{CONCLUSIONS}

The PSPS is a useful method for estimating forage and TMR particle size. Adding a sieve with a $1.18 \mathrm{~mm}$ aperture may improve the usefulness of the PSPS in describing particle size for dairy cows. Additionally, we have further investigated and described operation procedures of the PSPS and recommend that it be shaken at a frequency of $1.1 \mathrm{~Hz}$ or greater (66 cycles/ min) with a stroke length of $17 \mathrm{~cm}$. Lastly, we have investigated the effects of sample moisture on measurements. These results suggest that small moisture loss from collected samples may affect particle size, but these differences, when observed, are small. Conversely, completely drying a sample resulted in large differences in particle size results.

\section{ACKNOWLEDGMENTS}

This research was supported in part by USDA grant no. 97-34281-4590 and was a component of NC-1119, Management Systems to Improve the Economic and Environmental Sustainability of Dairy Enterprises. Appreciation is extended to T. Ross for assistance in particle size analysis.

\section{REFERENCES}

ASAE. 2001. S424. Method of determining and expressing particle size of chopped forage materials by sieving. In Standards Am. Soc. Agric. Eng., St. Joseph, MI.

Allen, M. S. 1997. Relationships between fermentation acid production in the rumen and the requirement for physically effective fiber. J. Dairy Sci. 80:1447-1462.

Allen, M. A., J. B. Robertson, and P. J. Van Soest. 1984. A comparison of particle size methodologies and statistical treatment. Pages 36-56 in Techniques in particle size analysis of feed and digesta. P. M. Kennedy, Ed. Can. Soc. Anim. Sci. Occ. Publ., Edmonton AB, Canada. 
Beauchemin, K. A., L. M. Rode, and M. J. Eliason. 1997. Chewing activities and milk production of dairy cows fed alfalfa as hay, silage, or dried cubes of hay or silage. J. Dairy Sci. 80:324-333.

Finner, M. F., J. E. Hardzinski, and L. L. Pagel. 1978. Evaluating particle length of chopped forages. ASAE paper No. 78-1047. Am. Soc. Ag. Eng., St. Joseph, MI.

Fischer, J. M., J. G. Buchanan-Smith, C. Campbell, D. G. Grieve, and O. B. Allen. 1994. Effects of forage particle size and long hay for cows fed total mixed rations based on alfalfa and corn. J. Dairy Sci. 77:217-229.

Fisher, D. S., J. C. Burns, and K. R. Pond. 1987. Estimation of mean and median particle size of ruminant digesta. J. Dairy Sci. 71:518-524.

Grant, R. J., V. F. Colenbrander, and D. R. Mertens. 1990a. Milk fat depression in dairy cows: role of silage particle size. J. Dairy Sci. 73:1834-1842.

Grant, R. J., V. F. Colenbrander, and D. R. Mertens. 1990b. Milk fat depression in dairy cows: role of particle size of alfalfa hay. J. Dairy Sci. 73:1823-1833.

Heinrichs, A. J., D. R. Buckmaster, and B. P. Lammers. 1999. Processing, mixing, and particle size reduction of forages for dairy cattle. J. Anim. Sci. 77:180-186.

Irani, R. R., and C. F. Callis. 1963. Particle Size: Measurement, Interpretation, and Application. John Wiley and Sons, Inc. New York, NY.

Kolmogoroff, A. N. 1941. About the logarithmic-normal law of distribution of particle dimensions generated by disintegration. Proc. Acad. Sci. USSR 31:99-101.
Lammers, B. P., D. R. Buckmaster, and A. J. Heinrichs. 1996. A simplified method for the analysis of particle sizes of forage and total mixed rations. J. Dairy Sci. 79:922-928.

Mertens, D. R. 1997. Creating a system for meeting the fiber requirements of dairy cattle. J. Dairy Sci. 80:1463-1482.

Murphy, M. R., and J. S. Zhu. 1997. A comparison of methods to analyze particle size as applied to alfalfa hay, corn silage, and concentrate mix. J. Dairy Sci. 80:2932-2938.

O'Dogherty, M. J. 1984. A description of chop length distributions from forage harvesters and geometric simulation model for distribution generation. Pages 62-76 in Techniques in particle size analysis of feed and digesta. P. M. Kennedy, ed. Can. Soc. Anim. Sci. Occ. Publ., Edmonton AB, Canada.

Pitt, R. E. 1987. Theory of particle size distributions for chopped forages. Trans. ASAE 30:1246-1253.

Poppi, D. P., and B. W. Norton. 1980. The validity of the critical size theory for particles leaving the rumen. J. Agric. Sci. 94:275-280.

San Emeterio, S. F., R. B. Reis, W. E. Campos, and L. D. Satter. 2000. Effect of coarse or fine grinding on utilization of dry or ensiled corn by lactating dairy cows. J. Dairy Sci. 83:2839-2848.

SAS User's Guide: Statistics Version 8 Edition. 2001. SAS Inst., Inc., Cary, NC.

Smith, L. W., R. A. Erdman, and E. Russek. 1984. Evaluation of logarithmic normal distribution and four single exponential distributions for describing cell wall particle size. Pages 83-93 in Techniques in particle size analysis of feed and digesta. P. M. Kennelly, ed. Can. Soc. Anim. Sci. Occ. Publ., Edmonton AB, Canada. 